
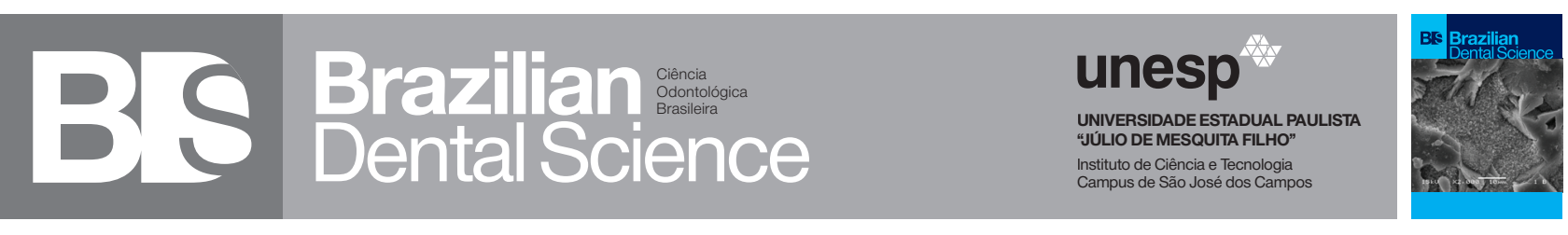

\title{
Prevalence and etiological factors of Piogenic Granuloma in gestants
}

\author{
Prevalência e fatores etiológicos do Granuloma Piogênico em gestantes
}

Ana de Lourdes SÁ DE LIRAㄹ, Nayra Rafaelle Fernandes da SILVA ${ }^{1}$, Vinícius da Silva CAETANO ${ }^{1}$, Ayrton Galvão de ARAÚJO JUNIOR ${ }^{1}$, Italo José Zacarias PORTELA ${ }^{1}$

1 - State University of Piauí - UESPI - School of Dentistry - Department of Pediatric Dentistry and Orthodontics - Area of Integrated Clinic - Parnaíba - PI - Brazil.

\begin{abstract}
Introduction: Neglect with oral health and hygiene will be reflected in the accumulation of biofilm and possible formation of supra and / or subgingival calculus, one of the etiological factors of Piogenic granuloma (PG). Objective: To investigate the prevalence and etiological factors of pyogenic granuloma in pregnant women. Method: The study was carried out on 102 pregnant women attending prenatal care in Family Health Strategies. The oral examination of the gingival tissue of the maxilla and the mandible was performed to evaluate the presence of PG, according to Neville et al classification, gingival bleeding, poorly adapted restorations, supra gingival calculus and residual roots. The chi-square test $(x 2)$ was used to investigate the degree of association between variables. Results: Prevalence of PG was $1.96 \%(\mathrm{n}=2)$ in the third semester of pregnancy. No pregnant woman had received information about the condition during prenatal care. Regarding the quality of bucaL hygiene, in 63 pregnant women it was considered unsatisfactory, with plaque visible and supragingival tartar in both arches and satisfactory in 39, with supragingival tartar in the lingual of the antero-inferiors and in the vestibular face of the upper molars associated to plaque visible on all teeth. The chi-square test demonstrated a greater need for scaling and corono-root straightening and removal of residual roots when associated with the pregnancy condition. Conclusions: The prevalence of pyogenic granuloma was $1.9 \%$ during the third trimester of gestation. As an etiological factor, the presence of too much dental calculus and visible plaque in both arches was found in $61.7 \%$ of the pregnant women.
\end{abstract}

\section{KEYWORDS}

Pyogenic granuloma; Pregnant women; Oral Health.

\section{RESUIMO}

Introdução: A negligência com saúde bucal e higiene se refletirá no acúmulo de biofilme e possível formação de cálculo supra e / ou subgengival, um dos fatores etiológicos do granuloma Piogênico (GP). Objetivo: Investigar a prevalência e os fatores etiológicos do granuloma piogênico em gestantes. Método: O estudo foi realizado em 102 gestantes que frequentavam o pré-natal nas Estratégias de Saúde da Família. O exame bucal do tecido gengival da maxila e da mandíbula foi realizado para avaliar a presença de GP, segundo a classificação de Neville e cols., Sangramento gengival, restaurações pouco adaptadas, cálculo supra gengival e raízes residuais. $\mathrm{O}$ teste do qui-quadrado $(\mathrm{X} 2)$ foi utilizado para investigar o grau de associação entre as variáveis. Resultados: A prevalência de GP foi de 1,96\% (n $=2$ ) no terceiro semestre de gestação. Nenhuma gestante havia recebido informações sobre a condição durante o pré-natal. Quanto à qualidade da higiene bucal, em 63 gestantes foi considerada insatisfatória, com placa visível e tegumentar supragengival em ambas as arcadas e satisfatória em 39 , com tártaro supragengival na língua dos anterossuprimários e na face vestibular dos molares superiores associado à placa visível em todos os dentes. O teste do qui-quadrado demonstrou maior necessidade de descamação e alisamento corono-radicular e remoção de raízes residuais quando associado à condição de gravidez. Conclusões: A prevalência de granuloma piogênico foi de 1,9\% durante o terceiro trimestre de gestação. Como fator etiológico, a presença de cálculo dentário em excesso e placa visível em ambos os arcos foi encontrada em $61,7 \%$ das gestantes.

\section{PALAVRAS-CHAVE}

Granuloma piogênico; Mulheres grávidas; Saúde Oral. 


\section{INTRODUCTION}

$\mathrm{T}$ he pathology called Pyogenic Granuloma (PG), also known as gravid granuloma, is classified as a tumor-like growth of cells similar to the oral cavity that has traditionally been considered benign and non-neoplastic [1].

It presents a varied etiology resulting from tissue responses to chronic and longterm stimuli, such as traumas, residual roots, decayed teeth, presence of biofilm from bad oral hygiene that culminates in periodontal disorders and subgingival dental tartar $[2,3]$.

It is clinically classified as an exophytic tissue volume increase having smooth or lobulated surface, which generally admits well circumscribed, pedunculated nodular forms, although some lesions are sessile. The surface may be ulcerated, with recurrent spontaneous or induced bleeding. Its coloration varies from pink to intense red [1].

Regarding the chronology of lesion appearance, it is observed that the younger the lesions, the more they will present an intense erythematous and vascular appearance, differing from older lesions that tend to become more collagenated and have a soft color close to rosacea $[3,4,5]$.

Piogenic Granuloma is more prevalent in females. It is found in about $5 \%$ of pregnant women and for this reason, the name "gravidic granuloma" is added, a synonymy used to refer to the disease in question. The nodular pathology occurs in approximately $77 \%$ of cases in the gingival region, being slightly more common in the maxilla than in the mandible, and may occur in other sites such as: tongue, lips, mucosa and less frequently on the hard palate $[6,7]$.

The pregnancy condition generates for women a series of hormonal disorders, which show an increase in the progesterone and estrogen hormone levels, causing dilation and proliferation of the gingival microcirculation and destruction of mast cells, resulting in an increase in the release of vasoactive substances in the adjacent tissue, inducing the formation of granuloma $[3,8]$.

Such carelessness with oral health and hygiene will be reflected in the accumulation of biofilm and possible formation of supra and / or subgingival calculus, one of the etiological factors of $\mathrm{PG}$, which will result in an inflammatory response on the part of the pregnant woman thus inducing the development of pathology $[9,10]$.

Thus, the objective of this study was to investigate the prevalence and etiological factors of pyogenic granuloma in pregnant women.

\section{METHOD}

A cross-sectional study of non-random clinical intervention in pregnant women attended to in the Family Health Strategies (FHS) in the city of Parnaíba-PI, previously approved by the Ethics and Research Committee (ERC) was numbered 1.991.879.

The estimated sample size was 130 pregnant women as a population representative of the municipality of Parnaíba-PI, considering the number of women of childbearing age between 14 and 44 years old assisted by FHS. After obtaining the sample, the study was withdrawn from 28 patients who decided to participate only in the lectures, not accepting be examined clinically. However, only 102 pregnant women accepted to participate in the survey, from the first to the ninth month of pregnancy, who underwent prenatal care in the 21 FHS from August 2017 to May 2018. Pregnant women who did not authorize the research and women attending the FHS who did not undergo prenatal care in the mentioned period were excluded. 
During the development of the research, researchers every month gave educational lectures to pregnant women, which were subsequently submitted to clinical examination in search of the PG during the pregnancy. Participants were informed about the importance of self-examination and maintenance of oral hygiene during the period of pregnancy.

The patients were examined by researchers who were trained at the Clinical School of Dentistry (CSD) of the State University of Piauí by means of calibration exercises with 10 pregnant women not participating in the sample plan, who received dental care at the CSD during their routine operation, this analysis being according to the methodology described by Peres et al.[11]

The pilot study involving 10 patients aimed to test the proposed methodology. As a result, its viability was observed without adjustments. To measure intra- and interexaminer diagnostic reproducibility, $10 \%$ of the total sample was double checked by each of the examiners, with the Kappa coefficient for intra- and inter-examiner agreement of 0.99 and 0.98 , respectively.

Oral examination of the gingival tissue of both arches was performed to evaluate the presence of PG, biofilm, calculus, gingival bleeding, and the presence of restorations which allowed the accumulation of biofilms and residual roots. It was considered as a criterion of clinical diagnosis the PG as the exophytic tissue volume increase pediculated or sessile, with smooth or lobulated surface, being able to present ulcerated, with recurrent spontaneous or provoked bleeding, with a color ranging from pink to intense red, according to Neville
[1]. Although the FHS had the dental surgeon in their setting, a differentiated follow-up was offered to the pregnant women preventive treatment throughout the gestational period at the CSD.

The first intraoral exam of them was performed at the Health Unit (HU) during the prenatal visits, in a reserved room, under artificial light, guaranteeing the patient's privacy. Using personal protective equipment (PPE), the oral cavity was inspected with a wooden spatula to remove mucous membranes and tongue. It was recorded in the odontogram when maladaptive restorations, residual roots, associated dental tartar and GP were found.

After this first stage of clinical investigation, the pregnant women were referred to the CSD. For biofilm control, dental prophylaxis and guidelines on oral hygiene were offered, and scraping with ultrasound and manual curettes was performed for treatment of supragingival tartar. Residual roots were removed, defective restorations were reworked and for the two patients who presented a PG compatible lesion, in addition to the above procedures, supragingival scraping and dental prophylaxis were used biweekly to prevent the evolution of PG, as the lesions did not interfere in chewing, brushing and swallowing, and patients do not wish surgical removal.

The PASW statistical package (Chicago, version 21) was used to tabulate and perform data analyzes. This allowed descriptive statistics (measures of central tendency and dispersion, frequency distribution), as well as the application of the chi-square test $(x 2)$ to investigate the degree of association between categorical variables. 


\section{RESULTS}

Sixty-three pregnant women (61.7\%) presented unsatisfactory oral hygiene, with visible plaque (biofilm) and supragingival tartar (calculus) in both arches and satisfactory in 39 (38.2\%), with tartar in the lingual of the antero-inferior and in the vestibular face of the molars associated with the plaque visible on all teeth. The prevalence of PG was $1.9 \%$, found in the vestibular region of the inferior arch, in the interdental papilla, on the right side between the premolars in two patients in the third trimester of pregnancy, who had already been examined at HU by the end of the second semester of pregnancy and were in need of scraping and corono-root smoothing and replacement of defective restorations (Table 1).

When they were assisted at CSD, the following week in the third trimester of pregnancy, the lesions were diagnosed and presented lobular delimitations of pedunculated character, pink coloration, painless, with $0.8 \mathrm{~cm}$ of diameter in the pregnant woman of 7 months and of $0.9 \mathrm{~cm}$ in the one of 8 months with slight bleeding during the brushing, in addition to the accumulation of tartar and visible plaque in both arches teeth.

Table 1 - Frequency distribution in relation to the studied variables

\begin{tabular}{|ccc|}
\hline Knowledge about pathology PG & $\begin{array}{c}\text { Absolute } \\
\text { Frequence } \\
\text { (n) }\end{array}$ & $\begin{array}{c}\text { Relative } \\
\text { Frequence } \\
\text { (\%) }\end{array}$ \\
\hline $\begin{array}{c}\text { Reported not to have knowledge about } \\
\text { pathology }\end{array}$ & 102 & 100 \\
\hline $\begin{array}{c}\text { Reported knowing how to prevent pathology } \\
\text { He reported frequent visits to the dentist } \\
\text { during gestation }\end{array}$ & 0 & - \\
\hline $\begin{array}{c}\text { Clinic school attendance (CSA) } \\
\text { Scraping and corono-root smoothing }\end{array}$ & 63 & 5.88 \\
\hline $\begin{array}{c}\text { Replacement of defective restorations } \\
\text { Removal of residual roots }\end{array}$ & 12 & 11.76 \\
\hline $\begin{array}{c}\text { Pregnant women with lesions compatible } \\
\text { with PG }\end{array}$ & 30 & 29.41 \\
\hline
\end{tabular}

There was remission of the PG approximately one month after the delivery of both pregnant women, after supragingival scraping and weekly biofilm control, since the patients did not accept the surgical removal of the lesion. In Table 1 the absolute and relative frequencies were expressed according to the variables studied.

We sought to investigate whether there were differences between the procedures discriminated for the present sample when applying the chi-square association test $\left(x^{2}\right)$.

In fact, for this analysis, the following values were observed: $x^{2}=(3), 51.8 \mathrm{p}<$ 0.001 for all variables. Such scenario indicates the rejection of the null hypothesis, that is, it was believed that the pregnant women presented adequate oral hygiene, with control of supragingival tartar and visible plaque. Thus, it was found that there were significant differences between observed and expected frequencies. Regarding the analyzed variables. In reviewing the descriptive statistics (Table 2 ) and (Figure 1) the procedures for scraping and corono-radicular smoothing and removal of residual roots were more strongly associated with the pregnancy condition of the present sample.

Table 2 - The chi-square association test ( $\mathrm{x} 2)$

\begin{tabular}{|c|ccc|}
\hline Variables & $\begin{array}{c}\text { Actual } \\
\text { Frequence }\end{array}$ & $\begin{array}{c}\text { Expected } \\
\text { Frequence }\end{array}$ & Residual \\
\hline $\begin{array}{c}\text { Need for scraping and corono- } \\
\text {-root smoothing }\end{array}$ & 63 & 30,5 & 32,5 \\
\hline $\begin{array}{c}\text { Replacement of defective } \\
\text { restorations }\end{array}$ & 12 & 30,5 & $-18,5$ \\
\hline Removal of residual roots & 30 & 30,5 & $-0,5$ \\
\hline Unknown etiological factors & 17 & 30,5 & $-13,5$ \\
\hline & & & \\
\hline
\end{tabular}




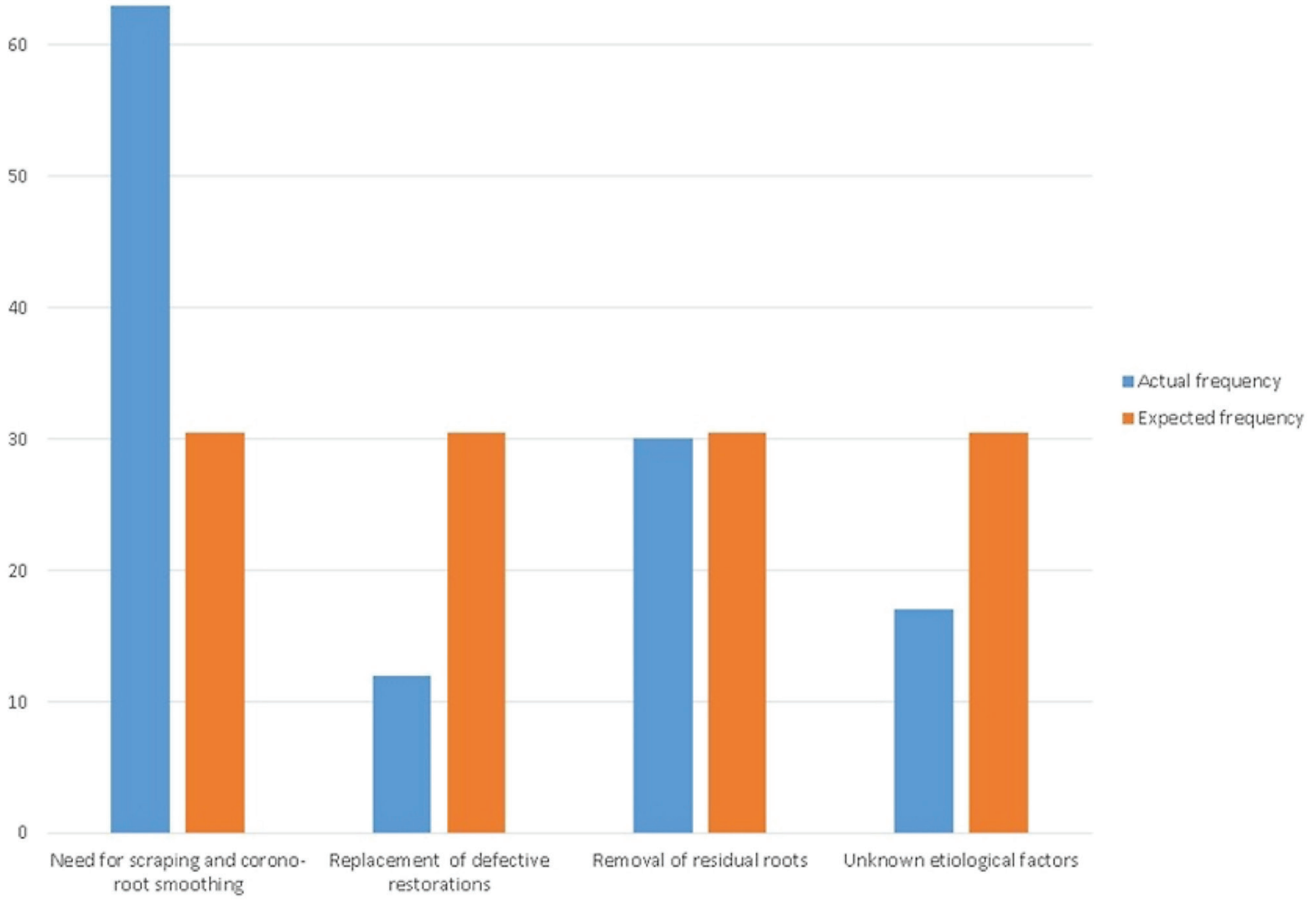

Figure 1 - Graphical representation of the chi-square association test (x2) for the studied variables.

\section{DISCUSSION}

Most pregnant women neglect their oral health in some way, often because they believe in popular hypotheses acquired through empirical referral, which report that regardless of the care that exists with their teeth, they tend to become more fragile and prone to tooth decay by excessive loss of calcium expended to the formation of bones and teeth of the developing child[9].

During pregnancy there is a change in the diet or eating habits of the woman, as well as changes in the frequency of her intake. On the other hand, oral hygiene does not accompany these new routines and sometimes tends to decrease due to nausea, sleep and other associated reasons [12,13,14]. As gingiva has receptors for steroid hormones, studies have pointed out that the increase of estrogen and progesterone would cause alterations in gingival physiology, which could intensify tissue response to local irritants and alter the local microbiota, with a predominance of more pathogenic microorganisms $[2,3,7]$.

According to the findings of the study, there were a few visits to the professional dental surgeon during the gestational period. Only a portion of $5.88 \%$ sought such professional follow-up. These data corroborate another study carried out in 2010, which found that only $9 \%$ of the pregnant women sought preventive dental care during pregnancy [10]. 
Other authors considered that 60\% of pregnant women did not use any type of dental service during pregnancy, although they reported having had access to it at some point during their life, but not necessarily during the gestational period $[12,13]$.

There was a low prevalence (1.96\%) of PG in the sample in the third trimester of pregnancy. Although Gaetti-Jardim et al[6] found that this pathology is present in less than $5 \%$ of the women, the prevalent gestational period was the first trimester.

The results of the research showed that all the pregnant women reported lack of knowledge about how to prevent PG and maintain oral health during the gestational period. Similar results were observed in other studies that reported on the fact that pregnant women using the public service received little guidance on oral health, and consequently did not value dental follow-up during this period $[13,14,15,16]$.

The accumulation of supragingival tartar and visible plaque was observed in most of the participants of this study, as was also verified in other studies $[17,18,19]$, which found similar findings between $60 \%$ and $75 \%$ of the pregnant women. The study by Martin et al. [14] emphasized that the negligence of oral hygiene caused the accumulation of biofilm with gingival inflammation and if not satisfactorily removed mineralizes forming a dental calculus, being considered as possible etiological factors of PG.

Residual roots and poorly adapted restorations were observed with biofilm accumulation and dental calculus. Numerous studies [16,17,18,21] have emphasized that biofilm and dental calculus are the main local irritants associated with PG, justifying the greater involvement of gingiva by inflammatory lesions, corroborating this research.

Both PG lesions occurred in the anterior and vestibular regions of the gingiva of two patients in the third trimester of pregnancy, which was shown in agreement with the studies performed by Choube et al. [20] and Cardoso et al. [21]. It should be noted that they presented accumulation of supragingival tartar and visible plaque, as well as defective restorations and residual roots, as were also observed by other authors [2,3,4,7,8,20,21,22,24] who considered that such mouth conditions are related to PG.

According to the procedure suggested by Riganelli et al. [22], supragingival scraping, replacement of defective restorations, removal of residual roots, observation and maintenance of oral hygiene were chosen, since the lesions were under control, without interference in chewing, swallowing, brushing and no spontaneous bleeding. Complete remission of PG occurred one month after termination of pregnancy, probably due to the control of plaque and tartar performed fortnightly and to the fact that the lesions presented reduced volume, corroborating other authors [21,22,23,24] when describing that depending on the volume, cure of the lesion may occur spontaneously after pregnancy and normalization of hormone levels.

\section{CONCLUSION}

It was concluded that the prevalence of pyogenic granuloma was $1.9 \%$ and occurred in the third trimester of gestation. As an etiological factor, the presence of supragingival dental tartar and plaque visible in both arches was observed. There is a need for awareness of the importance of oral hygiene during pregnancy as a preventive measure of pyogenic granuloma.

\section{REFERENCES}

1. Neville B, Allen CM, DammDD. Oral and Maxillofacial Pathology. $3^{\mathrm{a}}$ ed. Rio de Janeiro: Elsevier,2009.

2. China ALP,Souza NM, Amanajás TA, Pedreira EN. Pyogenic granuloma: reporting of atypical case on lower lip. Rev para med. 2010;24(3/4):14-7.

3. Reyes A, Pedron IG, Utumi ER, Aburad A, Soares MS. Pyogenic granuloma: focus at the periodontal disease as etiologic factor. Rev Clin Pesq Odontol. 2008; 4(1):29-33. 
4. Marinho TDFC, Pedro PDAS, Ana CLDA. Non-neoplastic proliferative processes: a literature review. Revista Saúde \& Ciência Online. 2016;5(2):94-110.

5. Brust AWA, Domingues JEG. Treatment and proservation of nine months in a patient with pyogenic granuloma: case report. Revista de Odontologia da UNESP.2009;38(3):192-7.

6. Gaetti-Jardim EC, Vieira JB, Castro AL, Gaetti-Jardim Júnior E, Felipini RC. Gravidarum granuloma - case report. R.F.0.2009; 14(2):153-7.

7. Gadelha MV, Gadelha RV, Porpino RM, Guede LMQ. Pyogenic granuloma on the lower lip: an unusual location. Revista Stomatos. 2012; 18(35):34-8.

8. Sills ES, Zegarelli DJ, Hoschander M, Strider WE. Clinical diagnosis and management of hormonally responsive oral pregnancy tumor (pyogenic granuloma).J Reprod Med. 1996; 41:467-70.

9. Benedito FCS, Joaquim DC, Farias AGS, CostaEC, Brito EHS, Leite ACRM. Oral health: knowledge and importance for pregnant women. Rev. Aten. Saúde. 2017; 15(52): 43-48. doi:10.13037/ras.vol15n524518.

10. Bastiane C, Cota ALS, Provenzano MGA, Fracasso MLC, Honório HM, Rios D. Pregnant's knowledge about oral alterations and dental treatment during pregnancy. Odontol. Clin.-Cient. 2010;9(2):155-60.

11. Peres MA, Traebert J, Marcenes W. Calibration of examiners for dental caries epidemiology studies. Cad Saúde Pública. 2001;17(1):153-9.

12. Bressane LB, Costa LNBDS, Vieira JMR, Rebelo MAB. Oral health conditions among pregnant women attended to at a health care center in Manaus, Amazonas, Brazil. Rev Odonto Ciênc. 2011;26(4):291-6.

13. Konzen Júnior DJ, Marmitt LP, Cesar J. Non-performance of dental consultation among pregnant women in southern Brazil: A population based study. Cien Saude Colet.2018;23(6):449-53.

14. Martins RFM, Azevedo JAP, Dourado CRL, Ribeiro CCC, Alves CMC, Thomaz EBAF. Oral health behaviors and dental treatment during pregnancy: a crosssectional study nested in a cohort in northeast Brazil. Pesq Bras Odontoped Clin Integr.2014;14(1):5-11.
15. Dalazen CE, De Carli AD, Jorje S. Oral Health in the Family Health Strategy: analysis of articles published in the period 2004-2014. Cien Saude Colet. 2016; 23(1):325-38. doi.org/10.1590/1413-81232018231.14412015.

16. Batistella FID, Imparato JCP, Raggio DP, Carvalho AS. Knowledge of the pregnant woman about oral health. RG0.2006;54(1):67-73.

17. Garcia-MartinJ M, Gonzalez-DiazA, Garcia-Pola MJ. Impact of oral health on the quality of life of pregnant woman. Rev. Salud Pública. 2017; 19(2):145-52. doi.10.15446/v19n2.55195

18. Moimaz SAS, Rocha NB, Garbin AJl, Garbin AS, Saliba 0. Influence of oral health on quality of life in pregnant women. Acta odontol. Latinoam. 2016; 29(2):186-93.

19. Vinay M, Ritesh SDKR, Hardik A. The Importance of Oral Health during Pregnancy:a review. MedicalExpress. 2018;5(11):1-6. doi: 10.5935 / MedicalExpress.2018.mr.002

20. Choube S, Joshi P, Rawlani SM, Chawla R, Rathi V,Mankar C. Pyogenic Granuloma - a case report. Acta Scientific Dental Sciences. 2018;2(8):86-89

21. Cardoso J, Spanemberg JC, Cherubini K, Figueiredo MA, Salum FG. Oral granuloma gravidarum: a retrospective study of 41 cases in Southern Brazil. Appl Oral Sci. 2013;21(3):215-8.

22. Riganelli L, Casorelli A, Caccetta J, Carrone A, Savone D,Merlino L etal. Granuloma gravidarum: clinical features and management. Case report and review of the literature. Giorn It 0st Gin. 2016.38(5/6):371-75. doi:10. 11138/ giog/2016.38.5.371.

23. Kanda N, Watanabe S. Regulatory roles of sex hormones in cutaneous biology and immunology. JDermatol Sci. 2005; 38:1-7.

24. Purwar P,Dixit J, Sheel V, Goel MM. Granuloma gravidarum: persistence in puerperal period an unuasual presentation. BMJ case report. $2015 \mathrm{Jan}$; 9:1-4. do: 10.1136/bcr-2014-206878

\section{Ana de Lourdes Sá de Lira} (Corresponding address)

Universidade Estadual do Piauí.

Faculdade de Odontologia Rua Senador

Joaquim Pires 2076 - Ininga. CEP: 64049-590.

Teresina - PI - Brasil.

Date submitted: 2019 Mar 22

E-mail: anadelourdessl@hotmail.com 